\title{
PEGARUH INTEGRATED MARKETING COMMUNICATION TERHADAP BRAND EQUITY PADA MCDONALDS A.YANI PADANG
}

\author{
Randi Surya Jaya, Febsri Susanti \\ Sekolah Tinggi Ilmu Eknomi "KBP" \\ febsrisusanti@akbpstie.ac.id
}

\begin{abstract}
Integrated Marketing Communication makes a very important role that has increased the ability of companies to be able to compete in the marketing environment that can be seen from total sales from 2014 to 2016. This study aims to analyze the Influence of Integrated Marketing Communication Against Brand Equity At Mcdonalds A. yani padang. This type of research uses quantitative methods. Population in this research is consumer of Mcdonalds A.yani padang. The number of samples in this study as many as 55 respondents with sampling techniques in this study using purposive sampling, the technique of determining the sample with certain considerations in the hope that bias can avoid the occurrence of bias on the results of this research. The technique used in testing the hypothesis is regression simple. While to test the hypothesis using statistical T test. The result of hypothesis testing shows that Integrated Marketing Communication to Brand Equity, which can be seen from t value equal to $(5,114)$ which means big from t table value $(0.000)$. This shows a positive and significant influence $(0.000<0.05)$. So accept the hypothesis $\mathrm{Ha}$ which states Integrated Marketing Communication have a positive and significant impact on Brand Equity. This shows that to achieve a high Brand Equity, Mcdonalds A.yani padang needs to improve Integrated Marketing Communication.
\end{abstract}

Keywords: Integrated Marketing Communication and Brand Equity.

\section{PENDAHULUAN}

Seiring dengan perkembangan zaman, lingkungan komunikasi pemasaran terus berubah dan berkembang semakin sulit. Terutama dengan berkembangnya inovasi teknologi yakni internet yang dapat meningkatkan persaingan di pasar. Hal ini menjadikan para pemasar harus mencari dan menggunakan strategi atau rencana komunikasi pemasaran yang jitu agar dapat bersaing dan tetap dapat mencapai tujuan organisasi/perusahaan. Strategi yang populer digunakan dalam rencana pemasaran untuk mengatasi persaingan pasar adalah komunikasi pemasaran terpadu atau Integrated Marketing Communication (IMC).

Komunikasi pemasaran terpadu adalah sebuah proses perencanaan marketingkomunikasi yang memperkenalkan konsep perencanaan komprehensif untuk mengevaluasi peranan strategis dari berbagai elemen komunikasi pemasaran, seperti Hubungan masyarakat, periklanan, penjualan langsung, promosi penjualan, dan pemasaran interaktif untuk memberikan kejelasan, konsistensi, serta pengaruh komunikasi yang maksimum. Dan dapat berperan penting untuk meningkatkan kemampuan perusahaan untuk mencapai pelanggan yang tepat dengan informasi yang tepat dalam waktu dan tempat yang tepat dengan menggunakan pilihan-pilihan komunikasi pemasaran. Pilihan-pilihan komunikasi tersebut biasa dikenal dengan istilah bauran komunikasi pemasaran (marketing mix). Maksudnya adalah mencapai sasaran konsumen yang tepat dan membantu organisasi atau perusahaan untuk mampu bersaing dalam lingkungan pemasaran yang sulit.

Untuk mampu bertahan dalam persaingan di lingkungan pemasaran yang semakin berubah, suatu organisasi perlu membangun suatu merek yang dapat mewakilkan citra dirinya kepada masyarakat terutama kepada pelanggan atau konsumen. Merek yang kuat atau yang biasa disebut branding menyuguhkan sejumlah manfaat bagi perusahaan termasuk berkurangnya kerentanan terhadap aksi pemasaran kompetitif, margin yang lebih besar, kerjasama perantara yang lebih besar dan dukungan, dan peluang perluasan (Fiani et al., 2012)

Komunikasi pemasaran atau marketing communication adalah cara suatu penjual, dalam hal ini perusahaan, untuk memberikan informasi dan mempengaruhi publik untuk membeli produk yang suatu perusahaan jual. Di dalam komunikasi pemasaran, terkandung branding dari produk yang dijual 
sekaligus citra dari perusahaan. Kegiatan ini juga merupakan usaha perusahaan dalam menjalin hubungan dengan calon konsumen maupun konsumen tetap. dapat memberikan informasi kepada konsumen tentang produk tersebut beserta cara penggunaan barang tersebut. Dengan adanya trategi yang di lakukan oleh Mcdonalds, hal itu berpengaruh pada penjualan di Mcdonalds A.yani padang beberapa tahun yang terakhir ini.

Berdasarkan latar belakang diatas, peneliti tertarik untuk meneliti lebih lanjut apakah Integrated Marketing Communication Terhadap Brand Equityberpengaruh terhadap pembelian penjualan dengan judul "Pengaruh Integrated Marketing Communication Terhadap Brand Equity pada Mcdonalds A.yani padang".

Komunikasi pemasaran terpadu (intregated marketing communication) adalah pencampuran dan pencocokan pilihan komunikasi yang berbeda untuk membangun kesadaran yang diinginkan terhadap citra dan gambaran yang dalam benak konsumen (Magister, Komunikasi and Undip, 2009). Meskipun komunikasi pemasaran memainkan sejumlah peran penting, komunikasi pemasaran dewasa ini akan bertambah sulit dengan lingkungan komunikasi pemasaran yang semakin berubah. Lingkungan komunikasi pemasaran telah berubah secara dramatis dalam beberapa tahun terakhir, termasuk juga di dalamnya lingkungan media (Fayshal et al., 2013) . Maka dari itu, para ahli pemasaran harus mempersiapkan strategi yang jitu untuk menghadapi persaingan. Strategi yang popular digunakan dalam rencana pemasaran untuk mengatasi persaingan pasar adalah komunikasi pemasaran terpadu atau Integrated Marketing Communication [IMC] (Adhi et al., no date2013). Selain itu, (Program et al., 2014) menjelaskan bahwa IMC atau komunikasi pemasaran terpadu mengandung peleburan darifungsi - fungsi komunikasi yang terpisah kedalam suatu cara yang memungkinkan organisasi untuk berbicara dengan "satu suara, satu wajah".

Fill dalam bukunya yang berjudul "Marketing Communications; contexts, content, and strategy" (2008) memberi satu contoh perusahaan yang berhasil dalam menggunakan konsep komunikasi pemasaran terpadu atau Integrated Marketing Communication (IMC), yaitu menu reguler dan menu breakfast. Menu reguler dan menu breakfast menunjukkan cara penggunaan yang efektif dari IMC ketika memasuki pasar Inggris. Es krim adalah makanan tradisional anak-anak musiman, dan pasar es krim saat itu hanya mengalami pertumbuhan atau inovasi yang sedikit. Strategi bisnis yang diterapkan menu reguler dan menu breakfast adalah untuk menciptakan segmen pasar baru, yang disebut sebagai segmen super premium.

Tujuan positioning-nya adalah untuk menyajikan menu reguler dan menu breakfast sebagai makanan yang mewah dan fashionable untuk orang dewasa. Untuk mencapai tujuan bisnis, seluruh bauran pemasaran dikoordinasikan: produk mencerminkan kualitas tinggi, harga yang tinggi mempengaruhi persepsi terhadap kualitas, dan distribusi dalam peluncuran itu melalui restoran restoran di lokasi prestisius dan hotel bintang lima di mana Mcflurry adalah satu - satunya es krim bermerek yang ada dalam menu. Kampanye promosi menggunakan selebriti dari berbagai lapisan masyarakat sebagai opinion leader untuk menciptakan efek riak pemasaran dari mulut ke mulut. Kualitas media yang digunakan dan pesan itu sendiri juga mencerminkan kualitas tema yang sama. Sejak saat itu, merek Mcflurry telah menjadi mapan dan meskipun kedatangan merek lain dari produk yang sama telah meningkatkan kompetisi dan persaingan, merek Mcflurry tetap khas dan terus menggunakan pendekatan yang terpadu (integrated) dalam komunikasi pemasarannya.

Penelitian yang dilakukan (Nandya et al., 2013) menunjukkan pengaruh persepsi konsumen Indoeskrim Meiji terhadap terhadap harga dan intensitas iklan pada dimensi ekuitas merek. Hasil penelitian menunjukkan bahwa dimensi persepsi kualitas merek memiliki kontribusi terendah dan bentuk hubungan yang negatif terhadap ekuitas merek. Hal tersebut dipengaruhi oleh variabel harga yang memiliki kontribusi terendah terhadap kualitas merek. Harga yang tinggi pada produk es krim ternyata akan membuat persepsi kualitas yang negatif terhadap produk tersebut. Hal tersebut menunjukkan bahwa harga yang tinggi belum tentu dikaitkan dengan produk yang mempunyai kesan kualitas yang baik. Harga yang terlalu tinggi bahkan menjadikan persepsi kualitas secara keseluruhan akan negatif dan bahkan menurunkan ekuitas merek. Dengan demikian, sudah jelas bahwa persepsi konsumen mempunyai pengaruh besar terhadap merek suatu organisasi/perusahaan. Hal ini dikarenakan gambaran atau persepsi yang ada dalam benak konsumen dapat mempengaruhi bagaimana sikap atau respon konsumen terhadap produk yang kemudian turut mempengaruhi ekuitas merek dari produk tersebut secara keseluruhan. 
Ekuitas merek adalah ukuran dari beberapa komponen, termasuk keyakinan, citra, dan asosiasi - asosiasi lain yang konsumen miliki terhadap produk tertentu (Hanandre and Widyawati, 2016) .Berikut terdapat beberapa pengertian dari ekuitas merek atau brand equity menurut ahli yang dikemukakan dalam beberapa penelitian:

(Pemasaran, Petra and Siwalankerto, 2013) menyatakan bahwa ekuitas merek adalah seperangkat aset dan keterpercayaan merek yang terkait dengan merek tertentu, nama dan atau simbol, yang mampu menambah atau mengurangi nilai yang diberikan oleh sebuah produk atau jasa, dalam hubungannya dengan konsumen atau pelanggan.

Ekuitas merek merupakan pengetahuan merek (brand knowledge) yang merupakan gambaran dan persepsi konsumen terhadap asosiasi merek (Rosilawati, 2008). (Semuel, Pemasaran and Petra, 2014) menyebutkan bahwa ekuitas merek adalah persepsi terhadap nilai suatu produk/merek yang ada dalam pikiran konsumen. (Wicaksono, 2014) mendefinisikan brand equity sebagai nilai tambah yang diberikan suatu merek kepada suatu produk dan jasa, direfleksikan dengan cara bagaimana seorang pelanggan, berfikir, merasakan, serta bertindak secara baik kepada sebuah merek. (Juanda et al., 2014) menyatakan bahwa ekuitas merek merupakan persepsi konsumen terhadap keistimewaan suatu merek dibandingkan dengan merek yang lain.

Ekuitas merek merupakan suatu keunggulan merek berdasarkan manfaat yang dirasakan oleh konsumen (Roti and Di, 2015). Dari penjabaran definisi ekuitas merek diatas, dapat dikatakan secara garis besar ekuitas merek merupakan persepsi konsumen atau gambaran yang ada dalam benak konsumen terhadap suatu merek tertentu. Brand equity atau ekuitas merek merupakan struktur pengetahuan yang ada dalam pemikiran atau benak konsumen mengenai merek tertentu. Dan komunikasi pemasaran memiliki peran penting dalam membentuk gambaran tersebut. (Unud, 2016) menyatakan bahwa komunikasi pemasaran memungkinkan perusahaan menghubungkan merek mereka dengan orang, tempat, acara, merek, pengalaman, perasaan, dan hal - hal lainnya. Mereka dapat berkontribusi pada ekuitas merek dengan menanamkan merek dalam ingatan dan menciptakan citra merek, serta mendorong penjualan dan bahkan memengaruhi nilai pemegang saham.

Menurut (Rahayu, no date), Ekuitas merek (brand equity) adalah seperangkat asosiasi dan perilaku yang dimiliki oleh pelanggan merek, anggota saluran distribusi, dan perusahaan yang memungkinkan suatu merek mendapatkan kekuatan, daya tahan, dan keunggulan yang dapat membedakan dengan merek pesaing. Menurut (Credibility et al., 2014), Ekuitas merek adalah seperangkat aset dan liabilitas merek yang berkaitan dengan suatu merek, nama dan simbolnya, yang menambah atau mengurangi nilai yang diberikan oleh suatu barang atau jasa kepada perusahaan atau pelanggan.

Menurut (Jiratchariyakul et al., 2013) Ekuitas merek adalah nilai yang ditentukan oleh konsumen pada suatu merek di atas dan di luar karakteristik/atribut fungsional dari produk. Merek adalah nama, bentuk, sinyal, simbol, atau desain atau kombinasi diantaranya yang mengidentifikasikan dan membedakan produk kita dengan pesaing . Kenapa (Hariadi and Martoatmodjo, 2012) mengatakan bahwa merek bukan sekedar nama besar saja, namun merek dilihat sebagai cara hidup. Didalamnya terdapat keinginan, janji dan komitmen yang harus dipenuhi perusahaan. Maka merek adalah total akumulasi dari semua pengalaman yang dialami dan dibangun berdasarkan kontak dengan konsumen.

Menurut penelitian penelitian (Rina, 2014) dengan judul "pengaruh integrated marketing Communication terhadap brand equity Perbankan syariah di kota malang"Menyatakan bahwa IMC berpengaruh terhadap brand equity pada bank pemerintah. IMC juga merupakan dimensi pembentuk brand awareness.

Penelitian lainnya menurut (Veronica, Prabela and Kumadji, 2016)Dengan judul "Pengaruh integrated marketing communication (imc) dan public relations terhadap citra merek dan keputusan pembelian"pengaruh Integrated Marketing Communication (IMC) dan Citra Merek yang signifikan secara bersama-sama terhadap Citra Merek karena memiliki nilai $p$-value 0,000 yang berarti $<0,05$ sehingga Ha diterima.

Menurut penelitian selanjutnya (Lauw Tjun Tjun Elyzabet Indrawati Marpaung, 2012) yang berjudul "Pengaruh komunikasi pemasaran terpadu dan ekuitas merek terhadap loyalitas konsumen" kedua variabel bebas yaitu komunikasi pemasaran terpadu dan ekuitas merek berpengaruh secara signifikan, sehingga pengujian dapat dilanjutkan ke tahap berikutnya. 


\section{METODE PENELITIAN}

Penelitian yang digunakan adalah dengan pendekatan kuantitatif. Dimana penelitian kuantitatif menekankan pada pengujian teori - teori melalui pengukuran variabel penelitian dengan angka dan melakukan analisis dengan prosedur statistik (Natalia et al., no date).

Objek penelitian Menurut Suharsini Arikunto (Sugiyono, 2015) adalah sebagai berikut:“'Objek penelitian adalah variabel atau apa yang menjadi titik perhatian suatu penelitian Objek dari penelitian ini adalah Restoran Mcdoonalds A.Yani Padang. Lokasi penelitian ini berada di Daerah Ahmad Yani Jl. Bandar Damar No.18, Olo, Padang Barat, Kota Padang, Sumatera Barat, Indonesia.

Populasi merupakan wilayah generalisasi yang terdiri atas subyek atau objek yang memiliki karakter \& kualitas tertentu yang ditetapkan oleh seorang peneliti (Matondang and Pendahuluan, 2009) untuk dipelajari yang kemudian ditarik sebuah kesimpulan. Populasi dalam penelitian ini adalah konsumen Mcdoonalds A.Yani Padang.

Sampel adalah himpunan bagian dari unit populasi. Sampel yang digunakan dalam penelitian ini adalah jumlah pelanggan Mcdonalds A. Yani Padang pada saat tahun 2014. Teknik pengambilan sampel dalam penelitian ini menggunakan purposive sampling, yaitu teknik penentuan sampel dengan pertimbangan tertentu. Purposive Sampling dipilih karena populasi pada penelitian yang telah diketahui dan diharapkan dengan penggunaannya dapat menghindari terjadinya bias pada hasil penelitian ini.sampel dalam penelitian ini sebanyak 55 responden

Jenis data yang di gunakan Untuk menganalisis pengaruh Integrated Marketing Communication Terhadap Brad Equity Pada Mcdonalds.Yani Padang maka data yang digunakan dalam penelitian ini adalah data kuantitatif. Data kuantitatif adalah data yang berbentuk angka atau data kualitatif yang diangkakan/scoring (Sugiyono, 2015:7).

Sumber Data dalam penelitian ini adalah Data primer merupakan data yang diperoleh secara langsung dari sumber asli (tanpa melalui perantara) dengan menggunakan metode survei (Astuti, 2014).Data primer pada penelitian ini diperoleh melalui pengisian kuesioner.

Kuesioner tersebut berisi pertanyaan-pertanyaan yang dapat memberikan gambaran mengenai Pengaruh Integrated Marketing Communication Terhadap Brad Equity Pada Mcdonalds. Yani Padang. Data sekunder adalah data yang diperoleh langsung dari sumbernya melalui dokumentasi atau yang telah diolah oleh pihak lain (Nofiawaty and Yuliandi, 2016).Untuk mengumpulkan data penelitian, kuesioner dipilih sebagai teknik pengumpulan data dalam penelitian ini.

Menurut(Neo-bis et al., 2014), Kuesioner atau angket adalah daftar pertanyaan yang diberikan kepada orang lain yang bersedia memberikan respon sesuai dengan permintaan pengguna. Agar peneliti dapat menggunakan data tersebut oleh peneliti untuk mengumpulkan data. 
Tabel 1.

Defenisi Operasional Variabel

\begin{tabular}{clll}
\hline $\begin{array}{c}\text { Varibel } \\
\text { Penelitian }\end{array}$ & \multicolumn{1}{c}{ Defenisi } & \multicolumn{1}{c}{ Indikator } & \multicolumn{1}{c}{ Sumber } \\
\hline Integrated & Merupakanupayaperusaha & IndikatordariKomunikasi & (Kartikasari, \\
Marketing & anmemadukandanmengko & PemasaranTerpaduadalahbaur & 2012) \\
Communi & ordinasikansemuasalurank & andarikomunikasi & \\
cation & omunikasiuntukmenyampa & pemasaranterpadu yang & \\
& ikanpesannyasecarajelas, & terdiridari : & \\
& konsistendanberpengaruhk & 1. & Iklan. \\
& uattentangorganisasidanpr & 2. acara/sponsor. & \\
& oduk-produknya. & 3. promosipenjualan. & \\
& & 4. pemasaraninteraktif. & \\
& & $5 . \quad$ beritadarimulutkemulut. & \\
& & 6. penjualan personal. & \\
& & 7. pemasaranlangsung. & \\
& & 8. Serta & \\
Brand & Nilai tambah pada suatu & Kinerjaprodukdalammemberi & (Kartikasari, \\
Equity & merek yang melekat pada & kannilaitambahpadasuatubara & 2012) \\
& suatu produk & ng. & \\
\hline
\end{tabular}

\section{Uji Validitas}

Data yang digunakan untuk di uji validitasnya adalah hasil skor dari kuesioner yang disebarkan kepada responden. (Yuniaris, Ekonomi and Muhammadiyah, 2006) mendefinisikan "Validitas adalah suatu ukuran yang menunjukkan tingkat kevalidan atau kesahihan suatu instrument". Sebuah instrument dikatakan valid apabilah mampu mangukur apa yang diinginkan. Pengujian hipotesis dilakukan terhadap item pertanyaan angket dengan cara mengkorelasikan setiap skor item dengan total skor item variabel lainnya. Jika validitasnya nyata dan bersifat positif maka $r$ hitung $>\mathrm{r}_{\text {tabel }}$, bila kurang dari 0,05 maka item dinyatakan tidak valid.

\section{Uji Reliabilitas}

Reliabilitas dimaksudkan untuk mengetahui kehandalan dan sejauh mana kebenaran alat ukur yang digunakan untuk mengukur sesuatu. Selain itu suatu instrument yang cukup dapat dipercaya untuk digunakan sebagai alat pengumpul data karena instrument tersebut sudah baik. (Yuniaris, Ekonomi and Muhammadiyah, 2006) Menjelaskan Reliabilitas Instrument (kuesioner) yang reliable artinya instrument tersebut dapat dipercaya, apabila data diambil beberapa kali dan hasilnya akan tetap sama. Dimana suatu angket dikatakan reliable jika nilai Cronbach Alfa lebih besar dari 0,60. Maka intem tersebut dinytakan Valid.

\section{Analisis Deskriptif (Uji TCR)}

Menghitung nilai Tingkat Capaian Responden (TCR)

$$
T C R=\frac{\text { Rata }- \text { rataskor }}{5} \times 100 \%
$$

Keterangan :

TCR = Tingkat Capaian Responden

Kamener(2017), mengemukakan Kriteria jawaban responden untuk Tingkat

Capaian Responden (TCR) adalah sebagai berikut: 
Tabel 2.

Rentang Skala TCR

\begin{tabular}{ccc}
\hline No & Angka & Keterangan \\
\hline 1 & $0 \%-54.9 \%$ & TidakBaik \\
2 & $55 \%-64.9 \%$ & KurangBaik \\
3 & $65 \%-79.9 \%$ & CukupBaik \\
4 & $80 \%-89.9 \%$ & Baik \\
5 & $90 \%-100 \%$ & SangatBaik \\
\hline
\end{tabular}

Sumber: Kamener(2017)

\section{Uji Normalitas}

(Sukotjo, 2010)Uji normalitas merupakan suatu alat uji yang digunakan untuk menguji apakah variabel- variabel yang digunakan dalam model regresi mempunyai distribusi normal atau tidak. Untuk mengetahui apakah data tersebut berdistribusi normal, dapat diuji dengan metode Kolmogorov Smirnov.Dengan menggunakan taraf signifikansi 0,05. Data dinyatakan berdistribusi normal jika signifikansi lebih besar dari 5\% atau 0,05 Dasar pengambilan keputusan.

1.Jika nilai Asymp. Sig> taraf signifikasi $(\alpha)$, maka $\mathrm{H}_{\mathrm{o}}$ ditolak dan $\mathrm{H}_{\mathrm{a}}$ diterima, hal ini berarti bahwa data tersebut berdistribusi secara normal.

2.Jika nilai Asymp. Sig < taraf signifikansi $(\alpha)$, maka $\mathrm{H}_{\mathrm{a}}$ ditolak dan $\mathrm{H}_{\mathrm{o}}$ diterima, hal ini berarti bahwa data tersebut tidak berdistribusi secara normal.

\section{Analisis Regresi Linear Sederhana}

Uji regresi berganda banyak sekali dipakai dalam penelitian. Pemakaian baik untuk keperluan skripsi ataupun penelitian sehari-hari(Veronica, Prabela and Kumadji, 2016) Kelebihan uji regresi adalah kemampuannya melakukan prediksi. Bagi kalangan guru sekolah atau dosen, uji regresi bisa dipakai untuk memprediksi perilaku siswa, baik dalam hal nilai atau perilaku-perilaku lainnya. Dalam penelitian ini digunakan analisis sebagai berikut :

$\mathrm{Y}=\mathrm{a}+\mathrm{e}$

Dimana:

$\mathrm{Y} \quad=$ Brand equity

a $\quad=$ Konstanta

$\mathrm{X} \quad=$ Integrated Marketing Communication

\section{Uji Hipotesis}

Menurut (Lauw Tjun Tjun Elyzabet Indrawati Marpaung, 2012) mengemukakan bahwa hipotesis adalah alternatif dugaan jawaban yang dibuat oleh peneliti bagi problematika yang diajukan dalam penelitiannya. Dugaan jawaban tesebut merupakan kebenaran yang sifatnya sementara, yang akan diuji kebenarannya dengan data yang dikumpulkan melalui penelitian. Adapun yang menjadi hipotesis utaman dalam penelitian ini adalah terdapat pengaruh integrated Marketing Communication terhadap brand equity pada Mcdonalds A.yani padang.

\section{Uji T.}

Uji $\mathrm{T}$ dikenal dengan uji parsial, yaitu untuk menguji bagaimana pengaruh masingmasing variabel bebasnya secara sendiri-sendiri terhadap variabel terikatnya. Uji ini dapat dilakukan dengan mambandingkan $\mathrm{t}$ hitung dengan $\mathrm{t}$ tabel atau dengan melihat kolom signifikansi pada masing-masing $\mathrm{t}$ hitung, proses uji $\mathrm{t}$ identik dengan Uji $\mathrm{F}$ (lihat perhitungan SPSS pada Coefficient Regression Full Model/Enter). Atau bisa diganti dengan Uji metode Stepwise(Yuniaris, Ekonomi and Muhammadiyah, 2006)

Hitung koefisien pengaruh dari variabel marketing communication terhadap variabel brand equitySebesar 6,74. Nilai t-hitung lebih besar dari t-kritis maka disimpulkan bahwa 
variabel marketing communication memiliki pengaruh yang signifikan terhadap variabel brand equity pada Mcdonalds. Hasil penelitian di atas membuktikan bahwa marketing communicationmempengaruhi brand equity.

\section{Uji Determinasi $\left(\mathbf{R}^{2}\right)$}

Koefisien determinasi digunakan untuk mengetahui persentase variabel independen secara bersama-sama dapat menjelaskan variabel dependen. Nilai koefisien determinasi adalah di antara nol dan satu. Jika koefisien determinasi $=1$, artinya variabel-variabel independen memberikan semua informasi yang dibutuhkan untuk memprediksi variasi variabel dependen. Jika koefisien determinasi $=0$, artinya variabel independen tidak mampu menjelaskan variasi variabel dependen.

\section{HASIL DAN PEMBAHASAN}

Proses pengolahan data dilakukan dengan menggunakan bantuan program Statistical Package for the Social Science (SPSS). Responden penelitian digambarkan secara umum dengan menyajikan karakteristik yang dilihat dari variabel demografi yaitu, jenis kelamin, usia, pendidikan terakhir dan lama kerja yang tercermin pada table 3.

\section{Tabel 3}

Karakteristik Demografi Responden

\begin{tabular}{|c|c|c|c|c|}
\hline No. & Variabel & Klasifikasi & $\begin{array}{l}\text { Jumlah } \\
\text { (orang) }\end{array}$ & $\begin{array}{c}\text { Persentase } \\
(\%)\end{array}$ \\
\hline \multirow[t]{2}{*}{1.} & JenisKelamin & Laki- Laki & 25 & 25 \\
\hline & & Perempuan & 30 & 30 \\
\hline \multicolumn{2}{|l|}{ Jumlah } & & 55 & 55 \\
\hline \multirow[t]{3}{*}{2.} & Umur & 11-20 tahun & 21 & 21 \\
\hline & & 21-30 tahun & 27 & 27 \\
\hline & & 31-40 tahun & 7 & 7 \\
\hline \multicolumn{2}{|l|}{ Jumlah } & & 55 & 55 \\
\hline \multirow[t]{3}{*}{3.} & Pendidikan & S1 & 16 & 16 \\
\hline & & S2 & 2 & 2 \\
\hline & & Sma & 37 & 37 \\
\hline \multicolumn{2}{|l|}{ Jumlah } & & 55 & 55 \\
\hline \multirow[t]{3}{*}{4.} & Masa & 1-tahun & 9 & 9 \\
\hline & & 2-tahun & 35 & 35 \\
\hline & & 3-tahun & 11 & 11 \\
\hline Jumlah & & & 55 & 55 \\
\hline
\end{tabular}

Berdasarkan Tabel 3 dapat dilihat bahwa jenis kelamin prempuan lebih banyak dibandingkan dengan Laki - laki ( Perempuan $=30 \%$ dan perempuan $=25 \%$ ). Kelompok usia terbanyak adalah responden dengan usia 21-30 tahun sebanyak 27 orang dengan persentase $49 \%$ dibandingkan dengan kelompok usia lainnya. Responden pendidikan terakhir SMA sebanyak 37 orang dengan persentase 37\%. Lama customer berlangganan, responden terbanyak yakni 2 tahun dengan persentase $2 \%$.

\section{Validitas}

Uji validitas menyatakan bahwa validitas tes pada dasarnya menunjuk kepada derajat fungsi pengukurnya suatu tes, atau derajat kecermatan ukurnya sesuatu tes. Validitas suatu tes mempermasalahkan apakah tes tersebut benar-benar mengukur apa yang hendak diukur. Maksudnya adalah seberapa jauh suatu tes mampu mengungkapkan dengan tepat ciri atau 
keadaan yang sesungguhnya dari obyek ukur, akan tergantung dari tingkat validitas tes yang bersangkutan. (Matondang and Pendahuluan, 2009). Dalam uji validitas Pengambilan keputusan berdasarkan pada nilai rhitung (Corrected item-Total Correlation) $>$ rtabel sebesar 0,3 Apabila nilai (Corrected item-Total Correlation) lebih besar dari 0,3 maka pernyataan dinyatakan valid.

\section{Integrated Marketing communication.}

Tabel 4

Item-Total Statistics

Hasil uji Validitas VariabelIntegrated Marketing communication (x)

\begin{tabular}{|c|c|c|c|}
\hline Variabel & $\begin{array}{c}\text { Corrected Item-Total } \\
\text { Correlation }\end{array}$ & Standar & Keterangan \\
\hline IMC1 & .477 & 0.3 & Valid \\
\hline IMC2 & .493 & 0.3 & Valid \\
\hline IMC3 & .572 & 0.3 & Valid \\
\hline IMC4 & .592 & 0.3 & Valid \\
\hline IMC5 & .585 & 0.3 & Valid \\
\hline IMC6 & .556 & 0.3 & Valid \\
\hline IMC7 & .518 & 0.3 & Valid \\
\hline IMC8 & .334 & 0.3 & Valid \\
\hline IMC9 & .535 & 0.3 & Valid \\
\hline
\end{tabular}

Sumber: SPSS 16

Dari tabel tersebut dapat diambil kesimpulan bahwa semua pernyataan dapat dikatakan valid karena Corrected item-Total Correlation melebihi 0,3 sehingga dapat dilanjutkan untuk penelitian lebih lanjut.

\section{Brand Equity}

Berdasarkan hasil perhitungan uji validitas variabel Brand Equitydengan sembilan item pernyataan dan semua pernyataan dinyatakan valid, seperti yang dikemukakan oleh tabel adalah sebagai berikut:

Tabel 5

Item-Total Statistics

Hasil uji validitas variabel Brand Equity $(\mathbf{Y})$

\begin{tabular}{lccc}
\hline \multicolumn{1}{c}{ Variabel } & $\begin{array}{c}\text { Corrected Item-Total } \\
\text { Correlation }\end{array}$ & Standar & Keterangan \\
\hline BE1 & .487 & 0.3 & Valid \\
BE2 & .620 & 0.3 & Valid \\
BE3 & .576 & 0.3 & Valid \\
BE4 & .687 & 0.3 & Valid \\
BE5 & .599 & 0.3 & Valid \\
BE6 & .783 & 0.3 & Valid \\
BE7 & .731 & 0.3 & Valid \\
BE8 & .529 & 0.3 & Valid \\
BE9 & .589 & 0.3 & Valid \\
\hline
\end{tabular}

Sumber : SPSS 16

Dari tabel tersebut dapat diambil kesimpulan bahwa semua pernyataan dapat dikatakan valid karena Corrected item-Total Correlationmelebihi 0,3 sehingga dapat dilanjutkan untuk penelitian lebih lanjut. 
Tabel 6

Hasil Uji Reliabilitas Variabel

Integrated Marketing Cummunication, Brand Equity

\begin{tabular}{|c|c|c|c|c|}
\hline No & Variabel & Cronbach' Alpha & Standar & Reliabilitas \\
\hline 1 & Integrated & & & Reliabel \\
\hline & $\begin{array}{l}\text { Marketing } \\
\text { Cummunication }\end{array}$ & 0,744 & 0.6 & \\
\hline 2 & Brand Equity & 0,765 & 0.6 & Reliabel \\
\hline
\end{tabular}

Sumber : SPSS 16

Dari tabel 6 dapat diambil kesimpulan bahwa dari uji reliabilitas dihasilkan nilai Cronbach's Alhpa untuk variabel penelitian yaitu Integrated Marketing Cummunication dan Brand Equity lebih dari 0,6 yang memberikan hasil bahwa variabel yang diteliti memenuhi syarat konsistensi (reliabilitas). Jadi item-item pernyataan untuk variabel penelitian sebagai alat ukur dalam penelitian.

3. Uji TCR

Tabel 7

Analisis Deksirptif Variabel Integrated Marketing Cummunication

\begin{tabular}{|c|c|c|c|c|c|c|c|c|c|c|c|c|}
\hline Indikator & No & SS & $\mathrm{S}$ & $\mathrm{R}$ & TS & STS & $\mathrm{N}$ & $\%$ & $\begin{array}{l}\text { Skor } \\
\text { Total }\end{array}$ & $\begin{array}{l}\text { Rata- } \\
\text { rata }\end{array}$ & $\operatorname{TCR}(\%)$ & Kriteria \\
\hline IMC & 1 & 16 & 17 & 22 & - & - & 55 & 100 & 214 & 389 & 77.8 & Cukup baik \\
\hline IMC & 2 & 26 & 23 & 6 & - & - & 55 & 100 & 240 & 436 & 87.2 & Baik \\
\hline IMC & 3 & 4 & 29 & 22 & - & - & 55 & 100 & 202 & 367 & 73.4 & Cukup baik \\
\hline IMC & 4 & 6 & 17 & 29 & - & - & 55 & 100 & 185 & 336 & 67.2 & Cukup baik \\
\hline IMC & 5 & - & 28 & 27 & - & - & 55 & 100 & 193 & 350 & 70.1 & Cukup baik \\
\hline IMC & 6 & 9 & 23 & 23 & - & - & 55 & 100 & 216 & 392 & 74.9 & Cukup baik \\
\hline IMC & 7 & 10 & 29 & 16 & - & - & 55 & 100 & 212 & 385 & 77.1 & Cukup baik \\
\hline IMC & 8 & 16 & 20 & 18 & 1 & - & 55 & 100 & 216 & 392 & 78.5 & Cukup baik \\
\hline \multirow{2}{*}{ IMC } & 9 & 3 & 21 & 31 & - & - & 55 & 100 & 190 & 345 & 69.0 & Cukup baik \\
\hline & $\begin{array}{l}\text { Rata- } \\
\text { rata }\end{array}$ & 3.28 & 67.5 & Cukup baik & & & & & & & & \\
\hline
\end{tabular}

Sumber : Hasil pengolahan SPSS versi 16 (2018)

Dari tabel diatas maka dapat bahwa kesimpulan dari tanggapan responden terhadap variabel kepribadian berada pada tingkatan keempat (baik), yaitu $80.18 \%$ yang terletak pada $80 \%$ sampai $90 \%$.

Tabel 8

Analisis Deksirptif Variabel Brand Equity

\begin{tabular}{|c|c|c|c|c|c|c|c|c|c|c|c|c|}
\hline INDIKTOR & No & SS & $\mathrm{S}$ & $\mathrm{R}$ & TS & STS & $\mathrm{N}$ & $\%$ & $\begin{array}{l}\text { Skor } \\
\text { Total }\end{array}$ & Rata-rata & $\mathrm{TCR}(\%)$ & Kriteria \\
\hline $\mathrm{BE}$ & 1 & 3 & 25 & 21 & 6 & - & 55 & 100 & 190 & 16.3 & 69.0 & Cukup baik \\
\hline $\mathrm{BE}$ & 2 & 8 & 19 & 23 & 5 & - & 55 & 100 & 195 & 35.4 & 70.9 & Cukup baik \\
\hline $\mathrm{BE}$ & 3 & 4 & 23 & 22 & 6 & - & 55 & 100 & 178 & 32.3 & 64.7 & Cukup baik \\
\hline $\mathrm{BE}$ & 4 & 11 & 21 & 19 & 4 & - & 55 & 100 & 224 & 40.7 & 81.4 & Baik \\
\hline $\mathrm{BE}$ & 5 & 2 & 25 & 20 & 8 & - & 55 & 100 & 180 & 32.7 & 65.4 & Cukup Baik \\
\hline $\mathrm{BE}$ & 6 & 10 & 13 & 24 & 8 & - & 55 & 100 & 190 & 34.5 & 69.0 & Cukup baik \\
\hline $\mathrm{BE}$ & 7 & 2 & 18 & 28 & 7 & - & 55 & 100 & 180 & 32.7 & 65.4 & Cukup baik \\
\hline $\mathrm{BE}$ & 8 & 9 & 20 & 19 & 27 & - & 55 & 100 & 195 & 35.4 & 70.9 & Cukup baik \\
\hline $\mathrm{BE}$ & 9 & 1 & 12 & 34 & 8 & - & 55 & 100 & 171 & 31.0 & 62.9 & Kurangbaik \\
\hline \multicolumn{10}{|c|}{ Rata-rata } & 2.91 & 68.6 & Cukup baik \\
\hline
\end{tabular}

Sumber : Hasil pengolahan SPSS versi 16 (2018) 
Dari tabel diatas maka dapat bahwa kesimpulan dari tanggapan responden terhadap variabel kepribadian berada pada tingkatan keempat (baik), yaitu $80.18 \%$ yang terletak pada $80 \%$ sampai $90 \%$.

\section{Uji Normalitas.}

Tabel 9

Hasil Uji Normalitas

One-Sample Kolmogorov-Smirnov Test

\begin{tabular}{llr}
\hline & & Standardized Residual \\
\hline $\mathrm{N}$ & & 55 \\
Normal Parameters & & \\
& Mean & .0000000 \\
Most Extreme Differences & Std. Deviation & .99069747 \\
& Absolute & .134 \\
& Positive & .062 \\
Kolmogorov-SmirnovZ & Negative & -.134 \\
Asymp. Sig. (2-tailed) & & .991 \\
\hline
\end{tabular}

a. Test distribution is Normal.

Sumber : SPSS 16

Dari Tabel diatas menunjukkan bahwa nilai Asymp. Sig sebesar $0.280>\alpha=$ 0,05 sehingga dapat dijelaskan bahwa data terdistribusi dengan normal.

\section{Uji Regresi Linear Sederhana}

Tabel 10

Hasil Uji Regresi Linear Sederhna

Coefficients $^{\mathrm{a}}$

\begin{tabular}{|c|c|c|c|c|c|c|}
\hline \multirow[b]{2}{*}{ Model } & & \multicolumn{2}{|c|}{$\begin{array}{l}\text { Unstandardized } \\
\text { Coefficients }\end{array}$} & \multirow{2}{*}{$\begin{array}{c}\begin{array}{c}\text { Standardized } \\
\text { Coefficients }\end{array} \\
\text { Beta }\end{array}$} & \multirow[b]{2}{*}{$\mathrm{t}$} & \multirow[b]{2}{*}{ Sig. } \\
\hline & & $B$ & Std. Error & & & \\
\hline \multirow[t]{2}{*}{$\overline{1}$} & (Constant) & 2.528 & 5.974 & & .423 & .674 \\
\hline & $\begin{array}{l}\text { Integrated } \\
\text { Marketing } \\
\text { Communication }\end{array}$ & .847 & .166 & .575 & 5.114 & .000 \\
\hline
\end{tabular}

a. Dependent Variable:Brand Equity

Berdasarkan hasil regresi yang didapat maka dibuat persamaan linear sederhana sebagai berikut:

$\mathrm{Y}=2.528+0.847 \mathrm{x}+\mathrm{e}$

Persamaan regresi diatas memiliki pengertian sebagai berikut:

$\mathrm{Y}$ (Brand Equity) $=(2.528)$ artinya secara rata-rata jika $\mathrm{x}$ tidak ada atau tidak terjadi peningkatan pengaruh pada Integrated Marketing Cummunication, maka Brand Equity akan mengalami penurunan sebesar (2.528).

$\mathrm{X}(\mathrm{Imc})=(0.847)$ artinya jika pengaruh Integrated Marketing Communication mengalami peningkatan sebesar $1 \%$ maka Brand Equity pada Mcdanalds mengalami peningkatan sebesar $85 \%$.

Untuk mengetahui model diatas layak digunakan atau tidak, hal ini dapat diketahui melalui tingkat signifikansi variabel bebas terhadap variabel terikat baik secara individual maupun secara keseluruhan, maka digunakan statistik uji-t.

Uji pengaruh Integrated Marketing Communication terhadap Brand Equity Pada Mcdonalds A.yani padang dapat ditentukan dengan langkah-langkah uji-T sebagai berikut : 
Ho : $=0$ ( Tidak ada pengaruh antara Integrated Marketing Communication terhadap Brand Equity ).

$\mathrm{Ha}: \neq 0$ ( Ada pengaruh antara Integrated Marketing Communication terhadap Brand Equity ).

Hasil Uji t

Tabel 11

Hasil Uji t

\begin{tabular}{|c|c|c|c|c|c|c|c|}
\hline \multirow[b]{2}{*}{ Model } & & \multicolumn{4}{|c|}{ Unstandardized Coefficients Standardized Coefficients } & \multirow[b]{2}{*}{$\mathrm{t}$} & \multirow[b]{2}{*}{ Sig. } \\
\hline & & $\mathrm{B}$ & Std. Error & Beta & & & \\
\hline 1 & (Constant) & 2.528 & 5.974 & & & .423 & .674 \\
\hline & $\begin{array}{l}\text { Integrated } \\
\text { Marketing } \\
\text { Communication }\end{array}$ & .847 & .166 & & .575 & 5.114 & .000 \\
\hline
\end{tabular}

a. Dependent Variable:Brand Equity

Berdasarkan hasil uji t pada tabel 11 dapat dilakukan analisa sebagai berikut:

Hasil uji t Integrated Marketing Communication terhadap Brand Equity 5.114 dengan nilai signifikan sebesar 0,000. Hal ini menunjukkan bahwa Integrated Marketing Communication berpengaruh terhadap Brand Equity karena nilai signifikan yang di peroleh lebih kecil dari pada taraf signifikan $0,05(0,00<0,05)$. Sehingga menerima hipotesis Ha yang menyatakan Intgrated Marketing Communication berpengaruh positif dan signifikan terhadap Brand Equity.

Uji Koefisien Determinasi $\left(\mathbf{R}^{2}\right)$

Tabel 12

Hasil Uji Koefisien Determinasi

Model Summary ${ }^{b}$

\begin{tabular}{lrrrr}
\hline Model & $\mathrm{R}$ & R Square & $\begin{array}{c}\text { Adjusted } \mathrm{R} \\
\text { Square }\end{array}$ & \multicolumn{2}{c}{ Std. Error of the Estimate } \\
\hline 1 & $.575^{\mathrm{a}}$ & .330 & .318 & \\
& & & &
\end{tabular}

a. Predictors: (Constant), Integrated Marketing Communication

b. Dependent Variable:Brand Equity

Sumber : SPSS 16

Dari hasil pengolahan data di atas terlihat bahwa nilai R-Square sebesar 0,330, hal ini berarti 0,33\% variabel Brand Equity (Y) akan dipengaruhi oleh variabel bebasnya yaitu Integrated Marketing Communication (x). sedangkan sisanya 99,67\% Brand Equity di pengaruhi oleh variabel-variabel lainnya yang tidak diteliti dalam penelitian ini.

\section{Pembahasan.}

Berdasarkan hasil pengujian hipotesis pertama ditemuka bahwa Integrated Marketing Communicationberpengaruh positif terhadapBrand Equity pada Mcdonalds A.Yani padang. Hal ini dapat dilihat dari hasil $\mathrm{T}$ hitung 5.114 dengan nilai signifikan sebesar $0.000<\alpha=0,05$ hal ini berarti signifikan $\mathrm{t}$ lebih kecil dari taraf signifikan (0.05).Penulis menemukan bahwa Integrated Marketing Communication berpengaruh positif secara signifikan terhadap Brand EquityMcdonalds A.Yani padang. 


\section{Kesimpulan}

Berdasarkan hasil analisis dan pembahasan hasil pengujian hipotesis maka dapat diajukan sejumlah hasil yang merupakan jawaban dari masalah yang diajukan didalam penelitian ini yaitu:

Berdasarkan hasil pengujian Ha dengan mengunakan uji T statistik ditemukan bahwa variabel Integrated Marketing Communication memiliki nilai sig < nilai alpha yaitu $(0,000$ $<0,05$ ). Maka dapat disimpulkan bahwa Integrated Marketing Communication berpengaruh positif dan signifikan terhadap Brand Equity pada Mcdanalds A.yani padang.

\section{DAFTAR PUSTAKA}

Adhi, W., Komunikasi, A., Terpadu, P., Asosiasi, D., Pada, M. And Jember, P. U. (No Date) 'Asosiasi Merek Pada Konsumen Minuman Isotonik Pocari Sweat ( Studi Pada Mahasiswa Fakultas Ilmu Sosial Dan Ilmu The Relationship Between Integrated Marketing Communication And Brand Association Of Isotonic Drink " Pocari Sweat " Consumer ( Study At Social Science And Political Science Faculty Stundents'.

Adji, P. And Dr. Hartono Subagio, S.E., M. . (2013) 'Pengaruh Retail Mix Terhadap Keputusan Pembelian Mahasiswa Uk Petra Di Circle K Siwalayankerto Surabaya’, Jurnal Manajemen Pemasaran Petra, 1(2), Pp. 1-10.

Astuti, S. R. T. (2014) 'Analisis Pengaruh Variabel Atmosfer Toko, Promosi Dan Pelayanan Pramuniaga Terhadap Impulse Buying Pada Kelas Konsumen Baru Di Kota Semarang', Jurnal Studi Manajemen \&Organisasi, 11, Pp. 178-201.

Bimo Kandogo, (2006;276). (2009) 'Peran Dari Integrated Marketing Communication Terhadap Brand Equity Ari Titis Bimo Kandhogo'.

Credibility, B., Credibility, E., Based, C., Equity, B. And Credibility, B. (2014) 'Pengaruh Dimensi Endorser Credibility Dimensi Consumer-Based Brand Equity Adiati Hardjanti Dan Hari Siswanto', 2.

Danibrata, A. (2008) 'Pengaruh Perluasan Merk Terhadap Citra Merk Pada Produk-Produk Pepsodent', 10(1), Pp. 37-46.

Fayshal, A., Medyawati, H., Pemasaran, M., Gunadarma, U., Ekonomi, F. And Gunadarma, U. (2013) 'Analisis Strategi Pemasaran Produk Asuransi Jiwa Pada Bumi Putera Syariah Cabang Depok', Pp. 48-58.

Fiani, M., Edwin, S., Pemasaran, J. M., Petra, U. K. And Siwalankerto, J. (2012) 'Analisa Pengaruh Food Quality Dan Brand Image Terhadap Keputusan Pembelian Roti Kecik Toko Roti Ganep ' S Di Kota Solo', 1(1), Pp. 1-6.

Hanandre, Y. T. And Widyawati, N. (2016) 'Pengaruh Ekuitas Merek Terhadap Keputusan Pembelian Di', 5.

Hariadi, D. And Martoatmodjo, S. (2012) 'Terhadap Keputusan Pembelian Konsumen', 1(8), Pp. 1-21.

Hidayati, R. R., \& Marlius, D. (2018). Aktivitas Promosi Dalam Meningkatkan Dana Pihak Ketiga Pada PT. Bank Perkreditan Rakyat (BPR) Batang Kapas Pesisir Selatan. 
https://oi.org/10.31227/osf.io/8dgqn

Jiratchariyakul, W., Beerhues, L., Mahady, G. B., Kummalue, T. And Vongsakul, M. (2013) 'Botanicals In Dietary Supplements', 2013, Pp. 2-4.

Juanda, F., Sondang, Y., Si, S., Sc, M., Pemasaran, J. M., Petra, U. K. And Siwalankerto, J. (2014) 'Analisa Pengaruh Visibility, Credibility, Attraction, Dan Power Celebrity Endorser Terhadap Brand Image Bedak Marcks Venus', 2(1), Pp. 1-8.

Kamener, D. (2017) 'Faktor - Faktor Yang Mempengaruhi Kualitas Strategi Bersaing Industri Ukm Bordiran / Sulaman Di Kota Padang', Journal Of Economic And Economic Education, 5(1), Pp. 90-105.

Kartikasari, N. P. (2012) 'Pengaruh Integrated Marketing Communication Terhadap Brand Equity Perbankan Syariah Di Kota Malangpengaruh Komunikasi Pemasaran Terpadu Terhadap Ekuitas Merek Nia Paramita Kartikasari'.

Lauw Tjun Tjun Elyzabet Indrawati Marpaung (2012) 'Pengaruh Kompetensi Dan Independensi Auditor Terhadap Kualitas Audit Lauw Tjun Tjun Elyzabet Indrawati Marpaung', 4(1), Pp. 33-56.

Magister, M., Komunikasi, I. And Undip, F. (2009) 'Peran Dari Integrated Marketing Communication Terhadap Brand Equity Ari Titis Bimo Kandhogo'.

Manajemen, J. (2016) 'Aktivitas Integrated Marketing Communications Terhadap Brand Image Untuk Industri Rokok Kelas Mild', (1), Pp. 23-33.

Matondang, Z. And Pendahuluan, A. (2009) 'Validitas Dan Reliabilitas Suatu Instrumen Penelitian', 6(1), Pp. 87-97.

Marlius, D. (2016). Pengaruh Bauran Pemasaran Jasa Terhadap Minat Nasabah Dalam Menabung Pada Bank Nagari Cabang Muaralabuh. https://doi.org/10.31227/osf.io/vdqgx

Marlius, D. (2017). Keputusan Pembelian Berdasarkan Faktor Psikologis Dan Bauran Pemasaran Pada PT. Intercom Mobilindo Padang. Jurnal Pundi. Volume 1. No. 1. Hal. 57-66. https://doi.org/10.31575/jp.v1 il.9

Nandya, I. G., Panasea, O., Wayan, N. And Suprapti, S. (2013) 'Peran Kepuasan Dalam Memediasi Pengaruh Komunitas Merek Terhadap Loyalitas Pengguna HarleyDavidson Di Kota Denpasar', 7(2), Pp. 86-95.

Natalia, L., Ekonomi, F., Manajemen, J. And Gunadarma, U. (No Date) 'Minat Konsumen Untuk Berbelanja', Pp. 1-11.

Neo-Bis, J., Chrismardani, Y., Manajemen, D. J. And Madura, U. T. (2014) 'Komunikasi Pemasaran Terpadu':, 8(2), Pp. 176-189.

Nofiawaty And Yuliandi, B. (2016) 'Pengaruh Atmosfer Toko, Promosi Dan Pelayanan Terhadap Keputusan Pembelian Konsumen Pada Matahari', Jurnal Ilmu Dan Riset 
Manajemen, 5(7), P. 2016.

Pemasaran, J. M., Petra, U. K. And Siwalankerto, J. (2013) 'Analisa Pengaruh Kepercayaan Terhadap Tenaga Penjual ( Trust In Employee ), Dan Kepercayaan Terhadap Merek ( Trust In Brand ) Terhadap Niat Beli ( Purchase Intention ) Konsumen Pada Bernini Furniture Di Surabaya , Dan Semarang .', 1(2), Pp. 1-12.

Program, P., Marketing, D., Keputusan, T., Meeting, M. And Lembang, G. H. (2014) 'Pengaruh Program Direct Marketing Terhadap Keputusan Menggunakan Meeting Package Grand Hotel Lembang (Survei Pada Tamu Bisnis Di Grand Hotel Lembang)', (1), Pp. 705-716.

Radityani, A., Kristanti, M., Program, D., Perhotelan, M., Ekonomi, F. And Kristen, U. (2005) 'Analisa Hubungan', Pp. 43-55.

Rahayu, Y. S. (No Date) 'Communication Terhadap Brand Equity', 1(2), Pp. 115-129.

Rina, A. W. (2014) 'Analisis Faktor-Faktor Yang Mempengaruhi Purchase Intention Melalui Social Media Marketing Terhadap Produk Frozen Yogurt Sour Sally Di Surabaya', 3(2), Pp. 37-44.

Rosilawati, Y. (2008) 'Employee Branding Sebagai Strategi Komunikasi', 6, Pp. 153-161.

Roti, P. And Di, C. (2015) 'Jurnal Manajemen Dan Bisnis Indonesia Vol. 1 No. 2 Desember 2015', 1(2), Pp. 143-161.

Semuel, H., Pemasaran, P. M. And Petra, U. K. (2014) 'Analisa Pengaruh Brand Image , Brand Trust Dan Economic Benefit Terhadap Niat Pembelian Polis Asuransi Pt . Sequislife Di Surabaya', 2(1), Pp. 1-11.

Sugiyono (2015) Statistik Nonparametris Untuk Penelitian. Edited By B. R. Setiadi. Yogyakarta: Alfabeta.

Sukotjo, H. (2010) 'Partisipant , Process , Dan Physical Evidence ) Terhadap Keputusan Pembelian Produk Klinik Kecantikan Teta Di Surabaya', Jurnal Mitra Ekonomi Dan Manajemen Bisnis, 1(2), Pp. 216-228.

Susanti, F. (2015). Pengaruh Bauran Promosi Terhadap Keputusan Klien Dalam Memilih Radio Carano Sebagai Media Promosi Iklan. https://doi.org/10.31227/osf.io/b9ws7

Unud, E. M. (2016) 'Pengaruh Celebrity Endorser Dan Brand Image Terhadap Fakultas Ekonomi Dan Bisnis Universitas Udayana ( Unud ), Bali , Indonesia

Veronica, C., Prabela, E. And Kumadji, S. (2016) 'Pengaruh Integrated Marketing Communication ( Imc ) Dan Public Relations Terhadap Citra Merek Dan Keputusan Pembelian ( Survei Pada Pengunjung Harris Hotel \& Conventions Malang )', Jurnal Administrasi Bisnis, 35(2), Pp. 155-163.

Weenas, J. R. S., Produk, K., Produk, K., Dan, P., Pelayanan, K., Ekonomi, F. And Manajemen, J. (2013) 'Kualitas Produk, Harga, Promosi Dan Kualitas Pelayanan Dan Pengaruhnya Terhadap Keputusan Pembelian Spring Bed Comforta', Jurnal Emba, 1(4), Pp. 607-618. 
Wicaksono, A. (2014) '( Studi Pada Konsumen Mobil Toyota Avanza Tahun 2012 Di Auto 2000 Malang Cabang Sukun )', 12(2), Pp. 1-10.

Yuniaris, W., Ekonomi, F. And Muhammadiyah, U. (2006) 'Pengaruh Integrated Marketing Communication Terhadap'. 